\title{
Management of Cultural Differences under Various Forms of China-UK Higher Education Strategic Alliances
}

\author{
Xiaoqing Li*, Joanne Roberts^, Yanni Yan ${ }^{\circledR}$ and Hui Tan \\ * Brunel Business School, Brunel University London, Kingston Lane, Uxbridge, \\ Middlesex, London, UB8 3PH, UK \\ ${ }^{\wedge}$ Winchester School of Art, University of Southampton, Park Avenue, Winchester, UK \\ @ Marketing Department, College of Business, City University of Hong Kong \\ Kowloon, Hong Kong, China.
}

\begin{abstract}
International strategic alliances are notorious for their high failure rate. Increased inter-partner conflict resulting from ineffective cross-cultural management is perceived to be one of the key reasons for unsatisfactory alliance performance. Driven by globalization, universities are extending into foreign markets through the establishment of various types of strategic alliances. Through an empirical investigation, this study reveals that although cultural differences exist in China-UK HE strategic alliances their impact depends on the structure of the strategic alliance. Although cultural conflicts occur more frequently in equity joint ventures than in non-equity modes, the impact of conflict arising from cultural differences is more serious and significant in non-equity arrangements. Moreover, partners perceive cultural differences as sources of mutual interest. The findings imply that the negative impact of cultural difference can be ameliorated to varying degrees depending on the type of China-UK HE strategic alliance.
\end{abstract}

Key words: cultural difference; strategic alliances; China-UK; higher education

Studies in Higher Education, 2014, DOI: 10.1080/03075079.2014.966664, Published online: 08 Oct 2014 


\section{Introduction}

International strategic alliances (ISA) have been seen as an important vehicle through which firms may realize their international expansion ambitions (Glaister and Buckley 1996). ISAs are notorious for short lives and high failure rate (as high as 70\%) (Das and Teng 2000). One of the important reasons for failure is inter-partner conflict deriving from cultural differences (CDs) between partners (Child, Faulkner and Tallman 2005; Hennart and Zeng 2002; Lane and Beamish 1990).

If the distance between the national cultures of the partners is large, it may create a cultural collision that may be detrimental to ISAs (Li and Guisinger 1991; Meschi and Riccio 2008). However, studies also find that certain cultures may be perceived as attractive to other cultures, and if CD is managed well, it may have a positive impact on alliance performance (Park and Ungson 1997; Shenkar 2001). Different cultures may be complementary to each other and, consequently, offer potential synergies. While research on the management of CDs in ISAs is imperative (Meirovich 2010), little research has been conducted on the extent to which the impact of CDs varies according to the type of ISAs, such as equity joint ventures (JVs) and non-equity alliances (Dong, Keith and Glaister 2007; Pothukuchi et al. 2002; Kumar and Das 2010). Moreover, as Leung et al (2005) argue, there is a need for research on ISAs and CD in different contexts. Although some research on ISAs in HE does exist, it has adopted a pedagogic perspective (De Vita 2010; Jiang et al 2010; Jones 2005; Smith 2010; Wang, Harding and Mai 2012), rather than addressing issues of strategic management (Shore and Groen 2009). Given the paucity of research on ISAs in the HE sector from a strategic perspective, this research addresses an important gap in knowledge concerning the international activity of universities.

International cooperation is no longer a choice but a developmental necessity in today's global market for HE (Chan 2004). Universities use ISAs to access foreign markets 'for the enhancement of their influences, visibility, and/or market share on the international scene' (Denman 2000, 5). By the end of 2011, the number of ISAs forming international branch campuses in the world had reached 200 compared to 162 in 2009, and another 37 are expected to open in the next two years, mainly from the UK and US (Lawton and Katsomitros 2012). Among the host countries, China is the fastest-growing destinations with a 70\% increase in ISAs by 2011 compared to 2009 , rising from 10 to 17 over the period (ibid). UK universities, which are the most prevalent in China, are involved in $20 \%$ of all China-foreign joint programs conferring bachelor or master degrees (MOE 2011). China is a typical country with an Eastern culture and the UK is a good representative of a Western culture (Hofstede 2007). Hence, an examination of the role of CD when partners from these two countries work together in a strategic alliance (SA) in HE, provides a valuable context within which to explore the role of $\mathrm{CD}$, how $\mathrm{HE}$ partners in different types of alliances deal with cultural conflicts, and how it impacts on performance. 
By empirically investigating key forms of China-UK HE ISAs, this study approaches the key stages of China-UK HE alliance formation, operation and development. It reveals the nature of CDs in China-UK HE alliances, and how their impact varies according to the type of ISA. Findings derived from this research are useful in providing insights for academics as well as practitioners when setting up international cooperative ventures in HE.

The paper first reviews existing research on CDs in ISAs and the relationship between the impact of CDs and the structure of ISAs. This is followed by the methodology section covering the definition of strategic alliance in HE, research method, data collection and data analysis. The findings, based on the data collected from multiple case studies, are then presented. In the penultimate section, these findings are discussed and their implications considered. The paper concludes with an account of the limitations of the study.

\section{Cultural differences in ISAs: barrier or value?}

Culture differences between alliance partners are found to be a source of misunderstanding and miscommunication (Makino et al. 2007). Partners, embedded in fundamentally different sets of social institutions, may demonstrate distinctiveness in managerial behavior (Hofstede 1991), responses to strategic and managerial issues, conflict resolution management, decision making and leadership style (House et al. 2004). In addition, trust is difficult to build between culturally distant alliance partners, leaving SAs vulnerable to management conflicts and early dissolution (Luo 2001). That is why firms perceive that collaboration is the second best option (Slater and Bobson 2012). Nevertheless, research reveals that the distance between national cultures in ISAs can contribute, as a critical component of complementarity, to the stability of strategic alliances, a source of admiration, value creating and learning for alliance partners (Park and Ungson 1997; Stahl and Voigt 2005). Greater complementarity between partners also leads to higher levels of trust and performance (Kim and Parkhe 2009), and listening to different points of view attributed to CDs improves the viability of ISAs (Patel 2007). Hence, CDs can offer sources of competitive advantages to a global firm, although this perspective has received less attention in the cross cultural literature (Yeganeh and Su 2006).

There are distinct differences between the UK and Chinese cultures in terms of power distance, individualism, and long/short-term orientation (Hofstede 2001, 2007). Power distance concerns the inequality formalized in the boss-subordinate relationships and is reflected in decision-making styles (Hofstede 2001). Where there is a high power distance (China), power and authority are given priority (Schwartz 1992), the subordinates fear disagreeing with their superiors, and therefore they defer to their bosses in decision-making; whereas when the power distance is low (UK), loyalty and responsibility are given priority (Schwartz 1992), individuals are more powerful in decision-making (Hofstede 2001). Individualism, as opposed to 
collectivism, describes the relationship between the individual and the collective that prevails in a given society (ibid). Individualism implies functional relationships, focusing on problem solving, and freedom of choice and competition. People from societies characterized by individualism are expected to take greater initiative and work independently. In contrast, collectivism emphasizes long-term relationships, considering group needs in decisions and paying attention to collective harmony and discipline (Hofstede 2007; Tse et al. 1988). The individualism/collectivism dimension (Hofstede 1980) correlates with low/high context paradigm (communication involves the uses of explicit and direct, or implicit and indirect message) (Gudykunst et al 1996; Hall 1976). High context culture coincides with collectivism while low context culture coincides with individualism (Gudykunst et al 1996). People from a low context and individualist culture tend to be open, direct, precise, and are more inclined to talk in communications. In contrast, people from a high context and collectivist culture are more concerned to avoid offending others by direct comments, hence they tend to use understatements, adjust communication to maintain harmony, and regard silence as a communicative act (ibid). The above differences, reflected in people's behavior in dealing with daily business activities, affect the management of ISAs. Whether such differences in national culture exert the same impact in all types of strategic alliances is not clear (Kumar and Das 2010). In particular, how the impact of CDs between partners varies in different types of China-UK strategic alliances in HE is a neglected issue.

\section{The management of CDs: the impact of CDs and the arrangement of ISAs}

How an alliance is arranged, namely, the level of operational integration within the cooperation has different consequences for the impact of CDs (Dong, Keith and Glaister 2007; Olie 1990, 1996). There might be two extremes (Olie 1990): one is a loosely coupled structure under which participating companies coexist with their own identity (e.g. contractual forms), leaving most of the original organizations intact; while the other extreme is where two organizations are closely interwoven under a combined structure leading to a new entity (e.g. a JV).

Dong, Keith and Glaister (2007) find that it is more likely that the effect of national CDs will be lower in equity-based China-foreign SAs (e.g. JVs) than in non-equity arrangements (e.g. contractual forms). Several factors account for this. First, the structural differences between equity and non-equity alliances should not be ignored (Das and Teng 1998). An equity JV is a separate legal entity established by two partner firms and it has its own board of directors and organizational hierarchy; while a non-equity alliance does not involve the creation of separate entities and partners just work jointly based on agreements (ibid). Within the organization of a JV, partners employ hierarchy and ownership to exert control while a non-equity alliance relies on contractual rigidities to manage cooperation (ibid). Therefore, equity-based ventures are structurally tighter than non-equity alliances, which suit the Chinese cultural tradition that emphasizes order, hierarchy, and the importance of relationships 
(Dong, Keith and Glaister 2007). Second, the close working relationship and frequent interactions between partners in equity-based alliances is conducive to trust building. Trust is helpful for solving cultural conflicts, and consequently, it can have a positive influence on alliance performance (Brouthers and Bamossy 2006). Third, partners selecting an equity-based structure are more interested in acquiring strategic knowledge through learning than those engaged in non-equity alliances (Kogut 1988; Li and Roberts 2012; Li, Roberts, Yan and Tan, 2013). Partners' learning attitude can help offset the negative impact of CDs (Barkema, Bell and Pennings 1996) between partners by exerting 'cognitive' (understanding the new system and how to do business within it) and 'behavioral' (adopting more effective practices) changes on managerial behaviors and operational routines (Child and Markoczy 1993). Besides 'cultural learning' (Meirovich 2010, 132) requires a receptive attitude to respond to the inputs and pressure from foreign partners. For instance, Gibson and Cohen (2003) find that in technology-intensive alliances, cultural clashes occurred when the team confronted the implementation of new technology. Once the technology had been adopted, through trial and error, the clashes were resolved, with learned experience the cultural proclivities were less of a factor in provoking conflicts. Fourth, the level of embeddedness (degree of mutual dependence and connectedness among the exchange parties) (Das and Teng 1998) is different in equity and non-equity alliances (Lavie, Haunschild and Khanna 2012). JVs require higher levels of alliance specific investments than non-equity alliances, and the investment in JVs is normally irreversible, whereas non-equity alliances involve little non-recoverable investment. Consequently, equity JVs are subject to higher exit barrier compared to non-equity alliances. Hence, partners in equity alliances are more embedded and dependent on each other and more likely to commit themselves to solving cultural problems than partners in non-equity alliances. Finally, compared to non-equity alliances, an equity $\mathrm{JV}$, as a long-term arrangement, provides partners with more opportunities to gain local experience and knowledge, which gradually helps to reduce the cultural gap. The above arguments indicate that an appropriate alliance design is conducive to resolving cultural problems as well as alliance viability (Patel 2007).

Nevertheless, the high level of integration in a JV requires close contact between both partners, so cultural problems, especially when the cultural distance between partners is large, will be more frequent than in less integrated forms of co-operations (Meijer, Duysters and Ulijn 2010). Within a hierarchical JV organization, partners have tighter control than those in non-equity alliances, where no equity investment is involved and so neither hierarchical nor ownership control is possible. Nevertheless, tighter control holds potential for greater friction between partners when cultural distance is large (Shenkar 2001). For instance, in equity JVs there are issues of staffing, reporting structure, procedures and policies on which managers rely to get the job done (Das and Teng 1998). When these activities involve people from different cultures, they offer potential for friction. In contrast, such issues and structures are absent in non-equity alliance, and consequently the frequency of cultural conflicts is lower, yet once conflict occurs in non-equity alliances it is more likely to lead to 
misunderstanding (Grotenhuis 2010), and to undermine the relationship than in an equity JVs. This is because in non-equity alliances communication between partners is mainly through email or the Internet rather than through face-to-face meetings, as is the case in JVs, and communication through new technology may intensify CDs (Hofstede 2001). Cross-border communication via technology not only makes the interpretation of messages more challenging, but also increases the difficulties of resolving cultural conflicts between partners in non-equity alliances.

The above arguments underline the importance of managing CDs for the successful development of equity JVs and non-equity alliances. Das and Teng (1998) argue that, due to the large amount of equity involvement in JVs, partners who are involved in equity JVs should have higher levels of confidence and trust while partners in non-equity alliances tend to have lower levels of trust and a limited ability to influence each other's behavior. Hence, within an equity JV structure, partners are more willing than those in non-equity alliances to deploy resources to support the operation in a foreign country, including the deployment of talented and dedicated managers who understand both cultures, to improve communications with local partners and help build strong networks (Fang 2010). People assigned by the two sides to implement the alliance are very important in resolving CDs as these people 'hammer out joint products' (Li and Hambrick 2005, 810). People who have bicultural competence (who have internalized two cultural schemas, Hong 2000, 94) can act as 'boundary spanners' (Child, Faulkner and Tallman, 2005, 353) or 'tie brokers' (Roth, Kostova and Dakhli 2011, 24) to perform bridging activities to help manage cultural conflicts. They have an empathetic understanding of partner's customs, values, beliefs, resources and commitments; an understanding of the technical issues involved in the relationship, and are able to explain and interpret the above to partners on both sides (Child, Faulkner and Tallman 2005; Hong 2010). In addition, they help ensure that the cooperation is conducted within the contact zone (social spaces where disparate cultures meet, clash and grapple with each other; where transculturation happens, Pratt 1992, 4, 6). The presence of these key persons in JVs helps reduce the impact of CDs to a lower level than that in non-equity alliances, where these key people are absent (Dong, Keith and Glaister 2007; Olie 1990). Given that the effects of national CDs vary in different types of alliances, in particular equity JVs and non-equity alliances, future research should focus on leveraging the alliance governance structure to manage CDs (Kumar and Das 2010), to reduce the impact of those differences that impede alliance success.

The majority of existing studies on the management of international HE strategic alliances have been conducted from a pedagogic perspective, such as, quality assurance (Smith 2010), cultural equivalence in assessment (De Vita 2010), international students' different approaches to learning and thinking or adaptation to cultural exposure in an overseas country (Jones 2005; Wang, Harding and Mai 2012), and staff's academic acculturation (Jiang, et al 2010). Research in this field has been based on either non-equity collaborations or regional networks (Ayoubi and 
Al-Habaibeh 2006; Chan 2004; Elkin, Farnsworth and Templer 2008). Few studies have examined a full range of types of international strategic alliances in HE or adopted a strategic management perspective in investigations of this emerging phenomenon (Shore and Groen 2009; Fielden 2011). This research is the first to investigate $\mathrm{CD}$ in HE ISAs from a strategic perspective and, in particular, to explore whether the impact of $\mathrm{CD}$ varies between equity and non-equity forms of China-UK HE strategic alliances.

\section{Methodology}

\section{Defining strategic alliances in $\mathrm{HE}$}

Parkhe (1991, 581) defines a business strategic alliance as:

'The relatively enduring interfirm cooperative arrangements, involving flows and linkages that utilize resources and/or governance structures from autonomous organizations, for the joint accomplishment of individual goals linked to the corporate mission of each sponsoring firm.'

Saffu and Mamman (2000) define strategic alliances in HE as any collaborative relationships between a local university and an overseas counterpart. Drawing on the business strategic alliance literature and studies of cross-border HE activity, this research defines a strategic educational alliance as consisting of at least the following essential elements:

- There are students involved in the process (students, being consumers as well as inputs and outputs of cooperative projects, are an indispensable part of a strategic educational alliance);

- There are equity or non equity commitments from the participating partners for the arrangement; (Parkhe 1991: a strategic alliance should involve flows and linkages of resources from both organizations);

- The whole process results in a degree certificate for the students, and both sides are involved in the degree course delivery (a degree represents a completion of a HE course; the involvement of both parts in the process defines the responsibility and eligibility of the two parts in the provision of the HE service);

- A degree course is delivered in a face-to-face manner rather than through distance learning. (This research focuses on normal campus-based learning; this is because the Chinese government does not recognize a degree obtained from a China-foreign cooperative project through distance learning, MoE 2011).

Therefore, 'links', arising from joint research labs or other research project collaborations in which students are not involved; and English preparation courses or foundation years in which the Chinese side does not carry the responsibility required of a degree course delivery, do not contain the necessary elements of a strategic alliance examined in this research. These activities were excluded from the study and they are defined as 'links' rather than 'strategic alliances' because the relationships between partners in these types of activities carry little or no strategic commitment. 


\section{Research design}

The case study method is often employed when dealing with 'how' and 'why' questions (Yin 2003). It can provide in-depth details with a small sample size (King, Keohane and Verba 1994). A multiple case study approach affords additional insights (King, Keohane and Verba 1994; Ragin 1987) underpinned by robustness of findings arising from replication and analytical generalization (Yin 2003). The purpose of this research is to investigate the role CDs play in China-UK HE strategic alliances, tackling questions including how partners manage CDs and why the impact of CDs varies in different forms of China-UK HE strategic alliances. Hence, an in-depth empirical examination based on a multiple case research design is considered suitable to help draw out insights on CD management in ISAs in the HE sector.

We firstly classified all China-foreign HE SAs based on a list of 384 partnerships (MoE 2009) into two types: equity JV and non-equity alliances (Pan and Tse (2000). Non-equity alliances account for $98 \%$ while there are only two equity JVs, accounting for $2 \%$. We categorize non-equity forms further: if a degree course is entirely taught in China, in which the 'consumers' (students) do not move between two countries, then this kind of cooperation is defined as a single-based alliance (SB). However, if the delivery of a degree course is split between both countries, and students move from one country to the other to complete the same degree program, the alliance belongs to a dual-based (DB) form. The latter has two sub-types: DB-validation and DB-franchise according to whether the courses taught in China are validated or franchised by UK partner universities. Ten cases were carefully selected in order to ensure that each form of alliance was represented in the total sample studied (Table 1). Each case has been in operation for at least two years to allow evaluation and comparison of the effect of $\mathrm{CD}$ and its management.

\section{Insert Table 1 about here}

\section{Data collection}

A pilot study was conducted in one of the SB cases, then, the fieldwork, mainly face-to-face interviews, was carried out with the ten case studies in China and the UK. Secondary information from records in the public domain concerning the operation of the case study alliances were reviewed and analyzed in parallel with primary data collection. The findings are the outcome of a reconciliation of analysis combining both primary and secondary data about the ten cases. In total, 41 interviews were conducted with those responsible for the cooperative project at various levels of the hierarchy in 20 organizations involved in the ten cases in both China and the UK. Each interview lasted for about 1.5 to 2 hours, with the longest being 2 hours 40 minutes. The interview questions were semi-structured and all interviews were recorded with prior agreement from the interviewees. 


\section{Data analysis}

There is no standardized approach to the analysis of qualitative data due to its diverse nature (Coffey and Atkinson 1996; Dey 1993; Miles and Huberman 1994). After verifying the collected data through a process of triangulation by comparing the information and evidence gathered, all the data were content analyzed. This involved the following steps: firstly, based on the research themes and cultural problems reported by interviewees in each case, the frequency and relevance of key variables were identified, recognizing relationship within and between categories of data (Saunders, Philip and Adrian 2003); secondly, the key sub-variables which have a bearing on the importance of the variables noted, and the factors which create and/or influence these were identified; finally, the meaning and implications of the results of the findings were deduced. All the interview transcripts from the ten cases were cross-searched for the variables. Then the method of 'pattern matching' (Yin 2003) was employed and the patterns of variable were then translated into analytical and theoretical language (Weber 1990). To ensure the validity of the data and avoid bias, the whole data analysis process was regularly communicated with experts through the presentation of conference papers and the key themes emerging from the data analysis were discussed and validated by two leading experts in the field of ISAs. Finally, the executive findings of the study were also informally presented to the case study universities; the feedback received was valuable and incorporated into this research. The evidence and analysis were finally constructed into the findings. A summary of key categories emerging from data analysis is detailed in Table 2.

Insert Table 2 about here

\section{Findings}

\section{Cultural differences in China-UK HE alliances: equity JV}

Interviewees in both JVs recognized the existence of CDs in different areas of the alliance operation. The tight organizational structure of JVs contributes to the frequent occurrence of problems arising from CDs. As shown in Figure 1-a, in both cases, the JV campus was owned 50/50 by the two partners, governed through a board with members from both sides, and managed through its own organizational hierarchy. To support the campus operation, the plan was for one third of the staff at the China campus to be seconded from the UK for the long-term. The secondees took key roles on the China campus, such as president, provost, leaders of academic faculties and other functional departments, covering administration, human resource, financial management, quality control and so on. When the UK secondees from a typical Western culture work in an Eastern context in China, CDs were described as 'clash points'. 
CDs are reflected in the different management styles. For instance, respecting a senior leaders' opinion was regarded as a polite way of making decisions in China (a reflection of high power distance in China). In the case JV2, when the seconded British vice-president took his office in China, he noticed that many Chinese staff members did not make decisions themselves therefore everything came to him. $\mathrm{He}$ told the Chinese staff 'You are subject to this, you make the decision,' but their response was 'but you are the boss, you make that decision'. At first he found this annoying and difficult to deal with but he quickly adapted to it. This phenomenon was quite common at the beginning of the operation in both JVs. CDs are also seen in the different ways that business is conducted.

'We have to come to terms with operating in an environment where what was written down is not as important as what they said; while in the west we spend a lot of time and money on lawyers drawing up written and legal documents in great detail'. (Resource Manager, UK, JV2)

In this instance, the CD clearly reflects the high context culture in China compared to the low context culture in the UK.

CDs are often found in daily academic activities when, for instance, UK staff teach Chinese students who display a learning styles nurtured in a high context culture. The following excerpt is illustrative of such CDs:

'I was shocked by a big round of applause when I was introduced to the students. Then when I taught, I had to think how to deal with the silence after I asked students the same questions as I did in the UK'. (A UK secondee, JV1)

Interviewees explained that CDs occur frequently in the operation of JVs, but 'they are not a barrier, it is just something that we need to be sensitive to at all stages' (seconded president, UK, JV1). They emphasized that the CDs that manifested themselves in the pedagogic traditions of the two different education systems, e.g. teacher-centered, passive or rote learning (China) versus student-centered, independent learning and critical enquiry (UK) (Jin and Cortazzi 2006; Samuelowicz 1987; Carson 1992), offered an opportunity for both sides to cooperate.

'Chinese students are fantastically good on technical forms, their mathematics skills are much better than the UK students; but they are weak on carrying on independent learning and problem-based group work. We are very strong for that in the UK, so what we try to do is to match the two things together; and try to create graduates who are better equipped to go into multinational firms and be able to work with the whole variety of different people. They understand the Chinese culture context as well as the western context' (Assistant director for transnational education, UK, JV1).

Each partner perceives that they lack a certain attribute that the other partner 
possesses. Courses provided by China-UK HE SAs were dedicated to narrowing the CDs. From the university's point of view CDs are deemed an important strategic asset. Partners in JVs intend to explore the benefits of learning from CD through the development of a full-fledged university in China. The comments of the Pro-vice Chancellor from the UK partner in JV1 demonstrate this intention:

'An unusual combination of a British university located in China will let us stand out from the crowd; we will gain culturally by operating a real university in a different context. The true experience and knowledge acquired by the staff and the university will become strategic assets and offer us a competitive advantage in the global market'. (Pro-vice Chancellor, UK, JV1)

Therefore, a JV offers an alliance structure that allows partners to be exposed to the full force of CDs, yet at the same time, it provides an appropriate structure to manage CDs. First, partners in JVs were found to be highly committed to the success of the cooperation. This was evidenced through the deployment of critical resources to the JV campuses in China. In both JVs, the first president of the China campus worked as senior managers in the UK and they were all Chinese (the Chinese Chancellor in JV1, and the Chinese Pro-Vice Chancellor in JV2). The presence of senior Chinese staff who understand both cultures on the boards and as leading forces in implementing the JV campuses was critical in helping reduce the impact of cultural conflicts. As the Chinese Pro-Vice Chancellor in the case of JV2 illustrated:

'In the UK, things are always white is white and black is black. But in China, things

sometimes could be white or black. When this happens, I need to explain to each side'.

Clearly, senior members of management who can act as boundary spanners bridging between the Chinese and UK cultures are key to avoiding and resolving cultural conflicts in the two China-UK HE JVs studied.

Second, a JV provides partners with a convenient platform to communicate in a face-to-face manner to resolve cultural conflicts. In the case of JV2, the vice-president is a professor of German who lived in another culture for many years. Benefitting from his previous experience, he managed the CD problems mentioned above very skillfully. He had many informal meetings with his Chinese colleagues and rather than telling them what to do, he asked them 'what do you think?' Gradually, people got used to that, as he said, eventually 'they stopped coming to report at all.'

Third, the reputation and equity investment in the JV increased the partners' interdependence. Consequently, partners in JVs are determined to make the JV successful. In the JV1, the brand new campus cost both sides about $£ 40$ million with facilities for 4000 students; while in JV2 two million pounds was invested by the UK partner. In addition to the equity engagement, the UK partners also brought intellectual property to the JV campus leading to a UK degree being issued in the territory of China. The JV partners' determination to succeed drove them to resolve CDs that might lead to conflict, and they saw CDs not as barriers but rather as learning opportunities. Finally, as the following quote illustrates, the long-term nature 
of a JV is conducive to acquiring and internalizing new cultural knowledge.

'I have been here (China campus) as a secondee for more than 3 years. What I have been interested in and felt valuable is the real experience of CDs, e.g. now I understand why I often receive short notices, and my Chinese colleagues have also understood why we require making appointments. We understand each other more than before, and the CDs attract us to learn more from each other.' (A secondee, UK, JV1)

CDs that staff met in their daily work were also brought into their class as vivid teaching cases. In addition, the Chinese partner learned from interacting with the Western partner in every aspect, including course design, teaching style and developing students' soft skills. Therefore, the benefits of learning offset cultural problems arising from CDs. Although CDs did impact on the two JVs, they did not impede their development and both JVs have grown rapidly.

\section{Cultural differences in China-UK HE alliances: non-equity alliances}

The non-equity alliances also experienced cultural problems but in comparison fewer than JVs. In the SB form of alliances, there is no a separate entity established by the two partners, instead a joint program (JP) was established between two departments of each partner's university operating on the Chinese partner's current campus, as detailed in Figure 1-b. A UK degree course is delivered entirely in China and the JP leads to a UK degree or dual degrees from each partner's university. The teaching of the course is shared 50/50 between the partners and the tuition fees were also split $50 / 50$ between both sides. A SB alliance needs to be approved by the Ministry of Education in China, but it exists by agreement and cooperation, not as an independent legal entity. This model is also called 'studying abroad at home' as it imports Western professors at key points for core modules, and students need not move to the UK to gain a UK degree.

Partners in SB alliances appreciate the CDs but are cautious in implementing their internationalization strategy and perceived a JV as a risky strategy. They recognize that a HE institution that wishes to remain at the forefront of education and research must develop robust collaborations around the world. The UK side analyzes the international market and perceives that competitive threats are developing in emerging countries, such as India and China. In order to avoid exclusion from these important education markets, they planned to pursue carefully targeted engagements. So, they utilize cultural opportunities and synthesize the resources of two parties to form one or two exciting international programs in their areas of strength and then expect to transplant the success to other departments at home. For example, in the case of SB2, the JP in China became a springboard for the UK partner to launch a triple-based project with China, Vietnam and India. The successful model demonstrated by the case of SB1 was applied in its medical department at home in setting up another partnership in India. 
In the SB alliances, the UK partner sends fly-in/out staff to stay for one or two weeks to deliver the core teaching content of a module in a block structure (intensive teaching of 1 or 2 weeks for a module, rather than spread over ten weeks). A block structure generally makes it possible for the UK courses to be taught by "core" staff. However, this is not always possible for a variety of reasons, for example, when one member of UK staff cannot fly to China for medical reasons. The method adopted by the case of SB1 is to recruit teaching fellows to form a teaching pair with one of the existing member of staff to share the workload in both the UK and China. The UK partners in both SB cases rejected further expansion of the cooperation because they were unable to commit more staff to delivering modules in China.

The joint steering and academic committees comprising senior members of both universities were set up to manage the cooperation and met twice a year. Cultural differences were mainly evident in the different management practices and different teaching and learning styles. As the following quote indicates, problems arising from CDs intensified when fly-in/out UK staff were present on the Chinese campus.

'We did not realize CDs until it comes to the real operation. They (the UK partner) have an examination board, an external examiner, a student, staff liaison committee, but we don't have. We use credit scores to decide whether students need to retake the course, while they use number of subjects. So we sit down to discuss until we reach an agreement.' (Director, China, SB1).

'I prepared myself for teaching two hours as same as I did in the UK, what surprised me was that our students in Beijing had prepared themselves beyond that. They had read the text book before the class started, they knew what I wanted to teach, so I had to discuss with our module leader to adjust the teaching content and speed.' (An academic member of staff, UK, SB1)

Although interviewees recognized the existence of CDs, they were not reported as a detrimental barrier to the collaboration, as the Director of the International College on the Chinese side in the case of SB1 noted:

'It is these differences originated from different cultures that cheer us up and learn.' Some good practices in management from the UK culture were applied in managing the JP and they were found to be effective, for instance, an examination board and external examiner, which are absent in Chinese universities, were established. The UK assessment and quality procedures prevented Chinese parents from using back door mechanisms (Guanxi) to influence student results.

In addition, to managing CDs in the cooperation, on the UK side there was a well established staff development program concerning cross-cultural issues. A consultancy service was also provided to departments with one-to-one coaching if needed. There was a special briefing for the staff prior to their first tour of duty in China, which covered cultural matters such as general cultural awareness and differences in students' learning styles. The UK lecturers quite enjoyed going to China 
to experience a different culture and some were beginning to learn Mandarin. Furthermore, the Chinese presence in the management team on the UK side and the installation of a team with either overseas study or work experience on the Chinese side were found to be effective in helping reduce the negative impact of CDs. For instance, in the case of SB1, the director of offshore operations responsible for the JP on the UK side graduated from the Chinese partner university. She was a postgraduate student of the president of the Chinese partner university and the first student from the Chinese side to do a $\mathrm{PhD}$ under the supervision of the head of the responsible department in the UK partner university. She knew both sides and both cultures. By acting as a boundary spanner between the partners she facilitated smooth communication between both sides. On the Chinese side, the director of the International College where the JP ran and the president of the Chinese partner university had overseas study experience in the UK. While, in the case of SB2, where there was only one manager who had UK study and work experience on the Chinese side, the Chinese interviewees complained that there were difficulties in communication with the UK partner particularly when the issue was related to understanding the Chinese culture. This underlines the importance of individuals who can take on boundary spanning roles in China-UK HE alliances.

In the DB franchise and validation forms of alliances, in which cooperation between the two parent universities does not occur through organizational integration, cultural opportunities are exploited by maximizing the use of existing resources to tap more overseas markets at low costs and risks. As displayed in Figure 1-c, in the DBfranchise alliances, part of a UK degree was taught in China by local tutors, the UK partner required and expected a consistency in the quality of course delivery in terms of teaching style, management, assessment, and language of instruction, but was unwilling to deploy resources to support the cooperation. The academic committee was established and met once a year to review the cooperation; the UK side paid visits twice a year to provide training for local tutors and/or to deliver sample lectures, but not to engage in everyday teaching. Although the local tutors had frequent virtual communications with course leaders in the UK, due to a lack of face-to-face communications, cultural barriers seemed to be difficult to overcome. This was particularly evident when local tutors interpreted UK designed teaching materials:

'The local tutors' interpretation of the materials may be different from that of the module leader here, as when the module leader designs it, he has his own thoughts to do in that way, and differences between the two cultures deteriorate the understanding of each other. Therefore, the communication is very difficult, normally taking several years. ' (Coordinator, UK, DB-franchise3)

Indeed, communications difficulties were further impeded by the time differences between the two countries, which delayed the exchanges of information.

In the DB-validation alliances, as shown in Figure 1-d, the course taught in China was designed and delivered by the Chinese staff, and validated by the UK partner as equivalent to part of a UK degree course, students need to move to the UK to 
complete the rest of course in order to achieve a UK degree. Limited resources were deployed to support the cooperation from the UK side. For instance, no committees were established to manage the cooperation, the UK side only assigned one or two coordinators to pay visits once or twice a year to interview students and issue offers to suitably qualified students to study in the UK. Partners made little efforts to absorb the value of CDs, as there were infrequent communications between staff from the two sides. The Chinese partner randomly sent staff to shadow UK lecturers or observe and learn the British management style, but its teaching was still conducted in Chinese and students were even assessed in Chinese in the case of DB validation 1.

The low level of communication in this type of alliance undermines the situation when cultural problems occurred. In the case of DB-validation 2, when the QAA (Quality Assurance Agency, UK) went to China to audit the cooperative project, the Chinese partner treated it as a very serious issue, and took it as an indication of the UK partner's suspicion of the Chinese side's quality of provision. The Chinese participants felt that they were not respected and thus were reluctant to cooperate. Because the alliance lacked members that could act as boundary spanners the problem remained unresolved for a long time. Indeed, as the following quote indicates, attempts to resolve the problem highlighted CDs:

'After the audit, the QAA wrote a report and launched it in a public ceremony. They (the Chinese partner) hadn't been sent it in advance, and that greatly insulted them - I was told. We had to explain it very carefully regarding why they were there in the first place. It was quite difficult because of different cultural backgrounds. I don't think we were successful eventually (Pro-vice Chancellor International, DB-validation 2, UK).'

The evolution and survival of this type of alliance was challenged when the British student visa policy changed in 2005 with the result that student numbers declined significantly in DB validation 2. Because these alliances were motivated by financial gains few resources were deployed. Consequently, the quality of the service offered by these alliances suffered. Due to little competence building through the partnership, the momentum for further development was lost in such alliances.

\section{Discussion and implications of the research}

Based on an in-depth empirical investigation into key forms of China-UK HE SAs, this study reveals how the impact of CDs varies in different types of alliances. Our findings shed light on the rarely explored subject of CD management in Sino-British HE alliances. The study finds that, cultural conflicts exist in different types of China-UK HE alliances, and are more frequent in the highly integrated mode - equity JV - than in non-equity modes, which is in line with Fielden (2011), who also reported the same findings based on six international partnerships in HE. However, the impact of conflict arising from CDs is more serious and significant in non-equity arrangements 
(increasingly stronger from SB, through $\mathrm{DB}$ franchise, to $\mathrm{DB}$ validation) than in equity JVs when it occurs. In non-equity alliances, most of the original organizational structure is intact (Olie 1990), the low degree of interdependence, as well as the less intensive face-to-face contact are not conducive for trust building. Due to a lack of trust and communications between partners, cultural conflicts seemed to be more difficult to resolve when they happened in non-equity modes. Particularly, partners in non-equity alliances intent on minimizing costs were less willing to deploy resources to the cooperation than those in equity JVs, hence, little learning was found in low integrative modes of alliances (e.g. DB validation).

Although it increases costs, this study finds that training and assigning academics, who had been exposed to both the Chinese and British cultures or had similar experience in other cultures, as 'boundary spanners' in the management team on both sides, is crucial in managing cultural conflicts (Fang 2010; Hong 2010; Li, Lam and Qian 2001; Leung et al. 2005; Tung and Verbeke 2010). Within the structure of non-equity arrangements, key boundary spanning academics were either absent on one side, or present in only a remote or temporary manner. In the low commitment type of alliances (e.g. DB validation) the long-standing unresolved cultural problems led to increased internal tension between partners, making this type of alliances vulnerable to external uncertainties. Practitioners should note that when choosing non-equity based alliances for cross-cultural cooperation employing key academics with multiple cultural backgrounds on both sides can go some way towards mitigating the negative effect of CDs and help to overcome cultural barriers. This is because these people could help partners deepen understanding of each other's culture and hence overcome difficulties in communication. They also help to establish trust between partners, and trust facilitates conflict resolution, eventually helping to fill the structural holes (Dong, Keith and Glaister 2007; Olie 1990). Our findings differ from those of Brouthers and Bamossy (2006) and Dong and Liu (2010) who claim that employing local people instead of expatriates in the operation of ISAs helps trust building and is hence conducive for managing CDs. In contrast, our findings reveal that over reliance on local staff to delivering a UK course in a China-UK HE alliance weakens the competitive advantage of the courses offered. UK expatriate staff remain an important aspect of the competitive advantage of China-UK HE alliances. Moreover, due to misinterpretations by local staff deriving from CDs, as well as the poor quality of virtual communication between partners in non-equity forms, trust is difficult to build in such alliances. Whereas in equity JVs, where UK secondees engage in course delivery over a long period, the face-to-face interaction between Chinese and UK staff helps to build trust.

Although the tight governance structure in JVs led to conflicts arising from CDs to occur more frequently than in loosely coupled alliances, in line with Dong, Keith and Glaister's (2007) findings, the negative impact of CDs was more likely to be contained in JVs than in non-equity alliances. The findings of this research reveal that JVs brought partners together to work in close proximity and engage in daily interaction. This facilitated the establishment of sound working relationships and built trust, which 
is conducive to resolving cultural problems. In addition, partners in China-UK HE JVs invested heavily in terms of equity and intellectual property. The high exit barrier together with the high degree of interdependence and connectedness drove partners to be determined and committed to the success of the cooperation. Hence, they seek to resolve cultural problems and to learn from CDs. JV partners treat CDs as strategic assets and solving cultural problems as opportunities to learn. In-depth learning enables both sides to absorb the essence of different cultures through common and divergent institutional practices (Shore and Groen 2009), to develop a shared managerial competence, and to acquire complementary skills. Hence the negative impact of CDs is mitigated, and learning from CDs positively influences the alliance evolution (Meirovich 2010; Steensma and Lyles 2000). Cognitive and behavioral changes are more likely to take place among partners in JVs, with both sides benefitting from cultural learning and cooperation.

Furthermore, the JV secondees with multicultural backgrounds located on the China campus for a lengthy period helped to overcome cultural barriers, their accumulated cultural experience and knowledge became significant assets of the JVs studied. Although the CDs between partners were particularly striking when dealing with non-academic issues, because these issues were not close to the value-added activities or purpose of the alliance (Sirmon and Lane 2004), they did not affect the outcomes of the JV campuses. Our findings also contribute to an understanding of why universities do not follow a uniform gradual market entry pattern (Li and Roberts 2012). Some universities progress directly to the establishment of a JV equity-based alliance because this form is more favorable for 'cultural synergy, cultural learning, and cultural problem-solving' (Dong, Keith and Glaister 2007, 203).

The contrasting impact of CDs in non-equity and equity China-UK HE alliances also reflects partners' different motivations in forming China-UK HE alliances. Partners adopting JVs strove to explore a wider range of opportunities created by CDs to enhance their competitive position in the global market, while partners engaged in SB were relatively cautious given the potential risk of investing in equity overseas. Hence, those in the latter form preferred to concentrate on one or two programs in their strong academic fields and then develop into other areas after initial success. Partners selecting DB-franchise and DB-validation modes focused on exploiting cultural resources to identify more market opportunities. No matter which mode partners chose, CD in HE ISAs was deemed to be of great value and an important reason for the establishment of educational alliances.

Indeed the findings show that the impact of CDs varies across different type of alliances. Overall, CD in HE does not appear to be such a detrimental factor as it is in the corporate world, where it is often cited as the major factor threatening the survival of alliances (Child, Faulkner and Tallman 2005; Hennart and Zeng 2002; Lane and Beamish 1990). This is mainly due to the different nature of education alliances when compared to business alliances. Education is the major agent of cultural transmission 
(Bourdieu and Passeron 1990) and this is an underlying purpose of many HE ISAs. In contrast, financial profit is the primary purpose in the business world. Consequently, CDs act as stimuli for UK and Chinese universities to cooperate, which support Beerkens and Derwende (2007) view that the national origins of partnering universities are important sources of complementarity in HE. Evidence from this research suggests that the ability to offer different cultural elements is an important attraction of China-UK HE SAs (Olie 1990; Meirovich 2010). Indeed, international universities should integrate an international dimension into their education to provide graduates with not only advanced knowledge but also cultural competence (Knight 1999; Kubota 2009).

Whether CD plays a major role in the evolution of China-UK HE alliances depends to a large extent on how the alliance is arranged and how conflicts arising from CDs are managed (Grotenuis 2010). Understanding the relationship between the impact of CDs and the type of alliances can help to guide the decisions of practitioners engaged in the planning and establishment of international ventures in HE between countries where the culture distance is large. Based on the examination of China-UK HE alliances, this research suggests that respecting CDs is the right attitude to adopt in international cross-cultural alliances in HE (Meirovich 2010). Moreover, learning from the differences should be encouraged in order to improve the skills, or 'intercultural competence' (Sercu 2004, p74), required to deal with CDs rather than trying to diminish or over-compensate for them.

\section{Limitation of the study}

We are aware that there are some limitations to this research. First, the cultural problems reported by interviewees were subject to their memory of past experience within the alliances. In general, only the most impressive parts of the events were remembered, some minor or trivial, but equally important points, from a research point of view, might be missed. This is one of the reasons why each case was approached from both sides of the strategic alliance and from different angles, hence allowing triangulation to take place throughout the research process. However, this can only minimize instead of prevent the loss of information and data. Second, the fact that there are only two JV cases with short life spans has constrained the extent to which the findings from this research may be generalized. Finally, this study takes the number of student enrollments as an indicator of alliance development and performance. However, the performance of a strategic alliance may be reflected in other indicators. 


\section{Acknowledgment:}

The authors thank Professor David Faulkner and Professor John Child, who acted as the first author's supervisors for the doctoral research from which this paper derives. The authors are particularly grateful to the anonymous reviewer for providing constructive comments and suggestions.

\section{References:}

Ayoubi, R.M. and Al-Habaibeh, A., 2006. An investigation into international business collaboration in higher education organizations-a case study of international partnerships in four UK leading universities. International Journal of Education Management, 20, no. 5: 380-396.

Barkema, H. G., Bell, J. H. J. and Pennings, J. M. 1996. Foreign entry, cultural barriers, and learning, Strategic Management Journal, 17, no. 2: 151-166.

Beerkens, E. and M. Derwende. 2007. The paradox in international cooperation: institutionally embedded universities in a global environment, Higher education, 53, no. 1: 61-79.

Brouthers, K. D. and Bamossy, G. J. 2006. Post-formation processes in Eastern and Western European joint ventures, Journal of Management Studies, 43, no. 2: 203-229.

Bourdieu, P. and Passeron, J . C. 1990. Reproduction in Education, Society and Culture, 2nd edition, London: Sage Publications.

Carson, J. 1992. Becoming biliterate: first language influences, Journal of Second Language Writing, 1, no. 1: 37-60.

Chan, W.W.Y. 2004. International cooperation in higher education: theory and practice, Journal of Studies in International Education, 8, no. 1: 32-55.

Child, J., D. Faulkner, and S. Tallman. 2005. Cooperative Strategy: Managing Alliances, Networks, and Joint Ventures, Oxford: Oxford University Press.

Child, J. and L. Markoczy. 1993. Host-country managerial behavior and learning in Chinese and Hungarian joint ventures, Journal of Management Studies, 30, no. 4: 611-631.

Coffey, A. and P. Atkinson. 1996. Making Sense of Qualitative Data: Complementary Research Strategies, London: Sage. 
Das, TK. and B. Teng. 2000. Instabilities of strategic alliances: an internal tension perspective. Organization Science, 11, no. 1: 77-103.

Das, T. K. and Teng, BS. 1998. Between trust and control: developing confidence in partner cooperation in alliances, Academy of Management Review, 23, no.3: 491-512.

Denman, B. 2000. Globalization and its impact on international university cooperation. Paper presented at the Organization for Economic Cooperation and Development-Program on Institutional Management in Higher Education Conference, Paris, September 2000.

De Vita, G. 2010. Cultural equivalence in the assessment of home and international business management students: a UK exploratory study, Studies in Higher Education, 27, no. 2: 221-231.

Dey, I. 1993. Qualitative Data Analysis: A User Friendly Guide for Social Scientists, London: Rutledge.

Dong, L., W. Keith and W. Glaister. 2007. National and corporate culture differences in international strategic alliances: Perceptions of Chinese partners, Asia Pacific Journal of Management, 24: 191-205.

Dong, K. and Liu, Y. 2010. Cross-cultural management in China, Cross Cultural Management: An International Journal, 17, no. 3: 223-243.

Lavie, D., Haunschild, P. and Khanna, P. 2012. Interorganizational differences, relational mechanisms, and alliance performance, Strategic Management Journal, 33, no. 12: 1453-1479

Elkin, G., J. Farnsworth and A. Templer. 2008. Strategy and the internationalization of universities. International Journal of Education Management, 22, no. 3:239-50.

Fang, T. 2010. Asian management research needs more self-confidence: Reflection on Hofstede 2007 and beyond, Asia Pacific Journal of Management, 27, no. 1: 155-170.

Fielden, J. 2011. Leadership and Management of international partnerships, Research and development series (series 2), London: Leadership Foundation for Higher Education.

Gibson, C.B. and S.G. Cohen. 2003. Virtual teams that work: creating conditions for virtual team effectiveness, Jossey-Bass: San Francisco. 
Glaister, K.W. and P.J. Buckley. 1996. Strategic motives for international alliance formation, Journal of Management Studies, 33, no. 3: 301-332.

Grotenhuis, F. 2010. Cross-border marriages: Dutch-Japanese and Dutch-American combinations, in J. Ulijn, G. Duysters, and E. Meijer (Eds.), Strategic alliances, mergers and acquisitions: the influence of culture on successful cooperation, 184-201). Cheltenham, UK: Edward Elgar.

Gudykunst, W.B., Matsumoto, Y., Ting-Toomey, S., Nishida, T., Kim, K. and Heyman, S. 1996. The influence of cultural individualism-collectivism, self construals, and individual values on communication styles across cultures, Human Communication Research, 22, no. 510-543.

Hall, E.T. 1976. Beyond culture. New York: Doubleday.

Hennart, J. and M. Zeng. 2002. Cross-Cultural Differences and Joint Venture Longevity, Journal of International Business Studies, 33, no. 4: 699-716

Hofstede, G. 1991. Cultures and Organizations: Software of the Mind: Intercultural Cooperation and its Importance for Survival, Cambridge, England: McGraw-Hill.

Hofstede, G. 2007. Asian management in the $21^{\text {st }}$ century, Asia Pacific Journal of Management, 24, no. 4: 411-420.

Hofstede, G. 2001. Cultures consequences: comparing values, behaviors, institutions and organizations across nations, Thousand Oaks, CA: Sage Publications.

Hong, H-J. 2010. Bicultural competence and its impact on team effectiveness, International Journal of Cross Cultural Management, 10, no. 1: 93-120.

House, R.J., P.J. Hanges, M. Javidan and P.W. Dorfman. Eds. 2004. Leadership, culture and organizations: the GLOBE study of 62 societies. Thousand Oaks, CA: Sage.

Jiang, X., Di Napoli, R., Borg, M., Maunder, R., Fry, H. and Walsh, E. 2010. Becoming and being an academic: the perspectives of Chinese staff in two research-intensive UK universities, Studies in Higher Education, 35, no. 2: 155-170.

Jin, L.X. and M. Cortazzi 2006. Changing practices in Chinese cultures of learning. Language, Culture, and Curriculum, 19, no. 1: 5-20. 
Jones, A. 2005. Culture and context: critical thinking and student learning in introductory macroeconomics, Studies in Higher Education, 30, no. 3: 339-354.

Kim, J. and A. Parkhe. 2009. Competing and cooperating similarity in global strategic alliances: and exploratory examination. British Journal of Management, 20, no. 3: 363-376.

King, G., R. Keohane and S. Verba. 1994. Designing social inquiry: scientific inference in qualitative research, Princeton: Princeton University Press.

Knight, J. 1999. A time of turbulence and transformation for internationalization, No.

14 CBIE Research Series, the Canadian Bureau for International Education, Ottawa.

Kogut, B. 1988. Joint ventures: Theoretical and empirical perspectives. Strategic Management Journal, 9, no. 4: 319-332.

Kubota, R. 2009. Internationalization of universities: paradoxes and responsibilities, The Modern Language Journal, 93, no. 4: 612-616.

Kumar, R. and T.K. Das. 2010. Strategic alliances and culture in a globalizing world, in J. Ulijn, G. Duysters, and E. Meijer (Eds.), Strategic alliances, mergers and acquisitions: the influence of culture on successful cooperation (pp.184-201). Cheltenham, UK: Edward Elgar.

Lane, H. and P. Beamish 1990. Cross-cultural cooperative behavior in joint ventures in LDCs, Management international review, 30: 87-102.

Lavie, D., Haunshild, P. R. and Khanna, P. 2012. Organizational differences, relational mechanisms, and alliance performance, Strategic Management Journal, 33, no. 13: 1453-1479.

Lawton, W. and Katsomitros, A. 2012 International branch campuses: data and developments, Observatory on Borderless Higher Education. The Observatory: London.

Leung, K.., R.S. Bhagat, N.R. Buchan, M. Erez and C.B. Gibson. 2005. Culture and international business: recent advances and their implications for future research, Journal of International Business Studies, 36, no. 4:357-378.

Li, J. and S.E. Guisinger. 1991. Comparative business failure of foreign-controlled firms in the United States, Journal of International Business Studies 22, no. 2: 209-224. 
Li, J. and D.C. Hambrick. 2005. Factional groups: a new vantage on demographic faultlines, conflict and disintegration in work teams, Academy of Management Journal, 48, no. 5: 794-813.

Li, J., K. Lam, and G. Qian. 2001. Does Culture Affect Behavior and Performance of Firms? The Case of Joint Ventures in China, Journal of International Business Studies, 32, no. 1: 115-131.

Li, X., J. Roberts, Y. Yan and H. Tan. 2013. Knowledge sharing in China-UK higher education alliances. International Business Review, in press http://dx.doi.org/10.1016/j.ibusrev.2013.05.001.

Li, X. and J. Roberts. 2012. A Stages Approach to the Internationalization of HE? The Entry of UK Universities into China, The Service Industries Journal , 32, no. 7: $1-28$.

Luo, Y. 2001. Antecedents and consequences of personal attachment in cross-cultural cooperative ventures. Administrative Science Quarterly, 46: 177-201.

Makino, S., C.M. Chan, T. Isobe and P.W. Beamish 2007. Intended and unintended termination of international joint ventures, Strategic Management Journal, 28, no. 11: 1113-1132.

Meijer, E., G. Duysters, and J. Ulijn. 2010. Culture, strategic alliances, mergers and acquisitions: an introduction, in J. Ulijn, G. Duysters, and E. Meijer (Eds.), Strategic alliances, mergers and acquisitions: the influence of culture on successful cooperation (184-201). Cheltenham, UK: Edward Elgar.

Meirovich, G. 2010. The impact of cultural similarities and differences on performance in strategic partnerships: an integrative perspective, Journal of Management \& Organization, 16: 127-139.

Meschi, P-X. and E.L. Riccio 2008. Country risk, national cultural differences between partners and survival of international joint ventures in Brazil, International Business Review, 17, no. 3: 250-266.

Miles, M.B. and A.M. Huberman. 1994. Qualitative data analysis: an expanded sourcebook, Thousand Oaks, CA: Sage Publications.

MoE, Ministry of Education, China. 2009. Part of information about China-foreign cooperation in running schools and programs, Ministry of Education, Beijing, China.

MoE. 2011. List of China-foreign cooperative programs, 4 January, Ministry of 
Education, China.

Olie, R. 1990. Culture and integration problems in internaitonal mergers and acquisitions, European Management Journal, 8, no. 2: 206-215

Olie, R. 1996. European transnational mergers, PhD thesis, State University Limburg, Maastricht, the Natherlands.

Pan, Y. and D.K. Tse. 2000. The Hierarchical Model of Market Entry Modes, Journal of International Business Studies, 31, no. 4: 535-554.

Park, S.H. and G.R. Ungson. 1997. The effect of national culture, organizational complementarity, and economic motivation on joint venture dissolution, Academy of Management Journal, 40: 279-307.

Parkhe, A. 1991. Interfirm Diversity, Organizational Learning, and Longevity in Global Strategic Alliances, Journal of International Business Studies, 22, no. 4: 579-601.

Patel, T. 2007. The role of dynamic cultural theories in explaining the viability of international strategic alliances: a focus on Indo-French alliances, Management Decision, 45, no. 10: 1532-1559.

Pratt, M.L. 1992. Imperial eyes: studies in travel writing and transculturation. London: Routledge.

Pothukuchi, V., Damanpour, F., Choi, J., Chen C., and Park,S.H. 2002. National and organizational culture differences and international joint venture performance, Journal of International Business Studies, 33, no. 2: 243-265.

Ragin, C. 1987. The Comparative Method: Moving Beyond Qualitative and Quantitative Strategies. Berkeley and Los Angeles: University of California Press.

Roth, K., Kostova, T. and Dakhli, M. 2011. Exploring cultural misfit: causes and consequences, International Business Review, 20: 15-26.

Saffu, K. and A. Mamman. 2000. Contradictions in international tertiary strategic alliances: the case from down under. The International Journal of Public Sector Management, 13, no. 6: 508-518.

Samuelowicz, K. 1987. Learning problems of overseas students: two sides of a story, Higher Education Research and Development, 6: 121-134. 
Saunders, M., L. Philip, and T. Adrian. 2003. Research Methods for Business Students. Harlow: Prentice Hall.

Schwartz, S. 1992. Universals in the content and structure of values, in M. Zanna (Ed.) Advances in experimental social psychology (25, 1-65). New York: Academic Press.

Sercu, L. 2004. Assessing intercultural competence: a framework for systematic test development in foreign language education and beyond. Intercultural Education 15, no. 1: 73-89.

Shenkar, O. 2001. Cultural distance revisited: towards a more rigorous conceptualization and measurement of cultural differences, Journal of International Business Studies, 32, no. 3: 519-535.

Shore, S. and Groen, J. 2009. After the ink dries: doing collaborative international work in higher education, Studies in Higher Education, 34, no. 5: 533-546.

Sirmon, D. G. and Lane, P. J. 2004. A model of cultural differences and international alliance performance, Journal of International Business Studies, 35, no. 4: 306-319.

Slater, S. and Robson, M. J. 2012. Social capital in Japanese-Western alliances understanding cultural effects, International Marketing Review, 29, no. 1: 6-23.

Smith, K. 2010. Assuring quality in transnational higher education: a matter of collaboration or control? Studies in Higher Education, 35, no, 7: 793-806.

Stahl, G.K. and A. Voigt. 2005. Impact of cultural differences on merger and acquisition performance: a critical research review and an integrative model. Advances in Mergers and Acquisitions, 4: 51-82.

Steensma, H.K. and M.A. Lyles. 2000. Explaining IJV survival in a transitional economy through social exchange and knowledge-based perspective. Strategic Management Journal, 21, no. 8: 831-851.

Tse, D.K., K. Lee, I. Vertinsky and D.A. Wehrung. 1988. Does Culture Matter? A Cross-Cultural Study of Executives' Choice, Decisiveness, and Risk Adjustment in International Marketing, The Journal of Marketing, 52, no. 4: 81-95. Tung, R. L. and A. Verbeke. 2010. Beyond Hofstede and GLOBE: Improving the Quality of Cross-Cultural Research. Journal of International Business Studies, 41, no. 8: 1259-1274.

Tung, R. L. and A. Verbeke. 2010. Beyond Hofstede and GLOBE: Improving the Quality of Cross-Cultural Research. Journal of International Business Studies, 
41, no. 8: 1259-1274.

Wang, Y., Harding, R. and Mai LW. 2012. Impact of cultural exposure on young students' adaptation in a UK business school, Studies in Higher Education, 37, no. 5: 621-639.

Weber, R.P. 1990. Basic Content Analysis, Newbury Park, CA: Sage.

Yeganeh, H. and Su, Z. 2006. Conceptual foundations of cultural management research, 6, no. 3: 361-376.

Yin, R.K. 2003. Case study research: design and methods, Thousand Oaks, Calif: Sage Publications. 
Table 1. Case study details

\begin{tabular}{|c|c|c|c|c|c|c|c|c|c|c|c|}
\hline \multirow{4}{*}{\multicolumn{2}{|c|}{101}} & \multicolumn{8}{|c|}{ Non-equity (98\%) } & \multirow{3}{*}{\multicolumn{2}{|c|}{$\begin{array}{l}\text { Equity (2\%) } \\
\text { Joint venture }\end{array}$}} \\
\hline & & \multicolumn{6}{|c|}{ Dual-based } & \multirow{2}{*}{\multicolumn{2}{|c|}{ Single-based }} & & \\
\hline & & \multicolumn{3}{|c|}{ Validation } & \multicolumn{3}{|c|}{ Franchise } & & & & \\
\hline & & $\begin{array}{c}\text { Case } \\
1\end{array}$ & $\begin{array}{c}\text { Case } \\
2\end{array}$ & $\begin{array}{c}\text { Case } \\
3\end{array}$ & $\begin{array}{c}\text { Case } \\
4\end{array}$ & $\begin{array}{c}\text { Case } \\
5\end{array}$ & $\begin{array}{c}\text { Case } \\
6\end{array}$ & $\begin{array}{c}\text { Case } \\
7\end{array}$ & $\begin{array}{c}\text { Case } \\
8\end{array}$ & $\begin{array}{c}\text { Case } \\
9\end{array}$ & $\begin{array}{c}\text { Case } \\
10\end{array}$ \\
\hline \multicolumn{2}{|c|}{$\begin{array}{c}\text { Years of } \\
\text { establishment }\end{array}$} & $2 \mathrm{ys}$ & $7 \mathrm{ys}$ & $9 \mathrm{ys}$ & $10 \mathrm{ys}$ & $6 y s$ & $5 y s$ & 4ys & $5 \mathrm{ys}$ & 6ys & 4ys \\
\hline \multicolumn{2}{|c|}{ Course Arrangement } & $2+2$ & $1+1$ & $1+1$ & $2 / 3+1$ & $3+1$ & $2 / 3+1$ & $4+0$ & $1+0$ & $\begin{array}{l}4+0 \\
2+0\end{array}$ & $\begin{array}{l}4+0 \\
2+0\end{array}$ \\
\hline \multirow{2}{*}{$\begin{array}{c}\text { Changes } \\
\text { in } \\
\text { number } \\
\text { of } \\
\text { students }\end{array}$} & $\begin{array}{c}\text { First } \\
\text { intake }\end{array}$ & 11 & 50 & 20 & 70 & 100 & 40 & 122 & 28 & 160 & 240 \\
\hline & $\begin{array}{c}\text { Intake in } \\
2009\end{array}$ & 13 & 33 & 0 & 200 & 60 & 150 & 500 & 48 & 4700 & 4000 \\
\hline
\end{tabular}


Table 2. The summary of key themes and categories emerging from the data analysis

\begin{tabular}{|c|c|c|c|c|c|}
\hline \multirow{4}{*}{\multicolumn{2}{|c|}{$\begin{array}{l}\text { Types of } \\
\text { alliances }\end{array}$}} & \multirow{3}{*}{ Equity JV } & \multicolumn{3}{|c|}{ Non equity } \\
\hline & & & \multirow[b]{2}{*}{ Single based } & \multicolumn{2}{|c|}{ Dual based } \\
\hline & & & & Franchise & Validation \\
\hline & & Case $10 \& 9$ & Case 8 \& 7 & Case 6, $5 \& 4$ & Case 3, $2 \& 1$ \\
\hline \multicolumn{2}{|r|}{$\begin{array}{l}\text { Nature } \\
\text { of } \\
\text { the alliance }\end{array}$} & $\begin{array}{l}\text { A new university set up by two } \\
\text { sides in China }\end{array}$ & $\begin{array}{l}1 \text { or } 2 \text { UK degree courses } \\
\text { entirely taught in China }\end{array}$ & $\begin{array}{l}\text { Part of a UK degree course } \\
\text { taught by local staff }\end{array}$ & $\begin{array}{l}\text { The course designed and } \\
\text { taught by the local staff, } \\
\text { validated by the UK side, as } \\
\text { equevelent as part of a UK } \\
\text { degree course }\end{array}$ \\
\hline \multicolumn{2}{|c|}{$\begin{array}{l}\text { Organizational } \\
\text { integration }\end{array}$} & $\begin{array}{l}\text { - University levlel; } \\
\text { - A new leagal entity with its } \\
\text { own hierarchy }\end{array}$ & $\begin{array}{l}\text { - Department level contact } \\
\text { - joint programs or jointly } \\
\text { delivering a UK program } \\
\text { - Contract based }\end{array}$ & $\begin{array}{l}\text { - Department level contact } \\
\text { - Replace the UK staff with } \\
\text { local tutors in teaching } \\
\text { - Contract based }\end{array}$ & $\begin{array}{l}\text { - Department level contact } \\
\text { - Articulation of } 1 \text { or } 2 \\
\text { programs } \\
\text { - Contract based }\end{array}$ \\
\hline \multicolumn{2}{|c|}{$\begin{array}{l}\text { Point where two } \\
\text { sides interface }\end{array}$} & $\begin{array}{l}\text { - UK secondees present on } \\
\text { campus } \\
\text { - Areas: } \\
\text { teaching } \\
\text { university management }\end{array}$ & $\begin{array}{l}\text { - UK staff teach } 50 \% \text { the } \\
\text { joint program } \\
\text { - Areas: } \\
\text { Teaching } \\
\text { Program management }\end{array}$ & $\begin{array}{l}\text { - UK staff visit } \\
\text { - UK staff virtually monitor } \\
\text { the teaching } \\
\text { - Area: } \\
\text { Teaching } \\
\text { Partial program managmt. }\end{array}$ & $\begin{array}{l}\text { - UK staff visit } \\
\text { - UK staff interview students } \\
\text { and issue offers } \\
\text { - Area: } 0\end{array}$ \\
\hline \multicolumn{2}{|c|}{$\begin{array}{c}\text { Dependence } \\
\& \\
\text { connectedness }\end{array}$} & $\begin{array}{l}\text { - Equity investment: yes } \\
\text { - University ownership: } 50 / 50 \\
\text { - Costs: } \\
\text { campus establishment } \\
1 / 3 \text { secondees; } \\
1 / 3 \text { internationally recruited } \\
\text { - Degree: a UK degree issued in } \\
\text { China; } \\
\text { - Exit barrier: high }\end{array}$ & $\begin{array}{l}\text { - Equity investment: no } \\
\text { - Costs: } \\
\text { flying-in/out staff } \\
\\
\text { - Degree: a UK/dual degree } \\
\text { issued in China } \\
\text { - Exit barrier: medium }\end{array}$ & $\begin{array}{l}\text { Degree: a UK degree } \\
\text { issued in the UK } \\
\text { - Exit barrier: low }\end{array}$ & $\begin{array}{l}\text { - Degree: a UK degree issued } \\
\text { in the UK } \\
\text { - Exit barrier: zero }\end{array}$ \\
\hline \multicolumn{2}{|c|}{ Motivation } & $\begin{array}{l}\text { - Explore cultural benefits } \\
\text { - Enhance reputation } \\
\text { - Strenthen position in the global } \\
\text { market } \\
\text { - Acquire competitive } \\
\text { knowledge through learning }\end{array}$ & $\begin{array}{l}\text { - Exploring cultural benefits } \\
\text { but causious of risks } \\
\text { - Tansplant the acquired } \\
\text { experience in other } \\
\text { departments } \\
\text { - Be involved in an } \\
\text { important market }\end{array}$ & $\begin{array}{l}\text { - Exploit cultural } \\
\text { opportunities for income } \\
\text { generation } \\
\text { - Gain stable student intake } \\
\text { to enhance survivability }\end{array}$ & $\begin{array}{l}\text { - Exploit cultural } \\
\text { opportunities for income } \\
\text { generation } \\
\text { - Recruit more overseas } \\
\text { students }\end{array}$ \\
\hline \multicolumn{2}{|c|}{$\begin{array}{c}\text { Alliance } \\
\text { management }\end{array}$} & Board, members from 2 sides & $\begin{array}{lll}\text { Joint } & \text { steering } & \text { and } \\
\text { academic } & \text { committees } & \end{array}$ & mic com & ent \\
\hline \multicolumn{2}{|c|}{$\begin{array}{c}\text { People involved } \\
\qquad \& \\
\text { their roles }\end{array}$} & $\begin{array}{l}\text { - Long-term seconded UK staff: } \\
\text { - Roles: president, provast, } \\
\text { department leaders, campus } \\
\text { construction manager, teaching }\end{array}$ & $\begin{array}{l}\text { - fly-in/out UK staff } \\
\text { - roles: members of } \\
\text { committees, program } \\
\text { leaders, teaching }\end{array}$ & $\begin{array}{l}\text { - Staff visit, once or twice a } \\
\text { year } \\
\text { roles: program leaders, } \\
\text { teaching staff }\end{array}$ & $\begin{array}{l}\text { - Staff visit: rare } \\
\text { - Roles: coordinator }\end{array}$ \\
\hline \multicolumn{2}{|c|}{ Committee meeting } & Face-to-face: often & Face-to-face: twice a year & Face-to-face: once a year & No \\
\hline \multicolumn{2}{|c|}{$\begin{array}{c}\text { Staff } \\
\text { communication }\end{array}$} & - Fac & $\begin{array}{l}\text { Face-to-face: short term } \\
\text { - MSN: often }\end{array}$ & $\begin{array}{l}\text { - face-to-face: } 1 \text { or } 2 \text { times/y } \\
\text { - MSN, email: often }\end{array}$ & - $\mathrm{Fa}$ \\
\hline \multicolumn{2}{|c|}{$\begin{array}{l}\text { Areas } \\
\text { of } \\
\text { CDs reported }\end{array}$} & $\begin{array}{l}\text { - Mangement } \\
\text { - Academic meet non-academic } \\
\text { - Teaching style }\end{array}$ & $\begin{array}{l}\text { - } \text { management } \\
\text { - Teaching style }\end{array}$ & $\begin{array}{l}\text { - Interpreting the UK } \\
\text { materials } \\
\text { - Teaching style }\end{array}$ & Understanding each other \\
\hline \multicolumn{2}{|c|}{$\begin{array}{l}\text { Frequency } \\
\text { of } \\
\text { CDs occurrence }\end{array}$} & High and striking, everyhwere & $\begin{array}{l}\text { Medium, only intensive } \\
\text { when fly-in/out staff are } \\
\text { present }\end{array}$ & $\begin{array}{l}\text { Low, only frequent when } \\
\text { communicating teaching } \\
\text { materials }\end{array}$ & $\begin{array}{l}\text { Rare, in understanding each } \\
\text { other }\end{array}$ \\
\hline \multirow{3}{*}{ 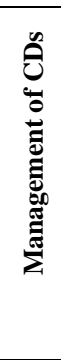 } & $\begin{array}{l}\text { UK: } \\
\text { presence of } \\
\text { Chinese staff } \\
\end{array}$ & $\begin{array}{l}\text { JV1. Chancellar } \\
\text { JV2:Pro-Vice-Chancellor }\end{array}$ & $\begin{array}{l}\text { SB1: director of offshore } \\
\text { operation } \\
\text { SB2: } 0\end{array}$ & $\begin{array}{l}\text { DB-F1: } 1 \text {, coordinator } \\
\text { DB-F2: } 1 \text {, coordinator } \\
\text { DB-F3: } 0\end{array}$ & $\begin{array}{l}\text { DB-V1: } 0 \\
\text { DB-V2: } 1 \text {, coordinator } \\
\text { DB-V3: } 0\end{array}$ \\
\hline & $\begin{array}{l}\text { China: } \\
\text { staff with } \\
\text { overseas } \\
\text { experience }\end{array}$ & $\begin{array}{l}\text { JV1: President, oveseas work } \\
\text { experience/Chancellor, UK } \\
\text { JV2: dean, previous education } \\
\text { consul, Chinese Embassy, UK }\end{array}$ & $\begin{array}{l}\text { SB1: president, UK study } \\
\text { SB2: project manager,UK } \\
\text { Master's degree study }\end{array}$ & $\begin{array}{l}\text { DB-F1: } 0 \\
\text { DB-F2: } 1, \text { UK study } \\
\text { DB-F3: } 1, \text { UK study }\end{array}$ & $\begin{array}{l}\text { DB-V1: } 1, \text { Australia, study } \\
\text { DB-V2: } 0 \\
\text { DB-V3: } \\
\text { 1, 1st group graduator }\end{array}$ \\
\hline & $\begin{array}{l}\text { Other } \\
\text { methods }\end{array}$ & $\begin{array}{l}\text { - Training } \\
\text { - Multicultural experience staff } \\
\text { - Use previous experience }\end{array}$ & $\begin{array}{l}\text { - Training } \\
\text { - Staff development prog. } \\
\text { - Use previous experience }\end{array}$ & $\begin{array}{l}\text { - Training provided to local } \\
\text { tutors } \\
\text { - Use previous experience }\end{array}$ & $\begin{array}{l}\text { Use previous experience: } \\
\text { From supervising Chinese } \\
\text { PhD students }\end{array}$ \\
\hline \multicolumn{2}{|c|}{ Impact of CDs } & $\begin{array}{l}\text { Resovled on site, not } \\
\text { detrimental }\end{array}$ & $\begin{array}{l}\text { Create difficulties in } \\
\begin{array}{l}\text { communication, } \\
\text { detrimental }\end{array}\end{array}$ & $\begin{array}{l}\text { Taking several years to } \\
\text { understand each other, not } \\
\text { detrimental }\end{array}$ & $\begin{array}{l}\text { Serious if it occurs, difficult } \\
\text { to resolve, not detrimental if } \\
\text { managed well }\end{array}$ \\
\hline \multicolumn{2}{|c|}{$\begin{array}{c}\text { Alliance } \\
\text { development }\end{array}$} & $\begin{array}{l}\text { Grow rapidly to a full-fledged } \\
\text { univeristy }\end{array}$ & $\begin{array}{l}\text { Increased in students, then } \\
\text { stable }\end{array}$ & $\begin{array}{l}\text { Uncertain: change of } \\
\text { partners/ courses/ or deline }\end{array}$ & $\begin{array}{l}\text { Terminated or delined in } \\
\text { number of students/ }\end{array}$ \\
\hline
\end{tabular}


Figure 1. The structure of equity and non-equity types of China-UK strategic alliances in HE

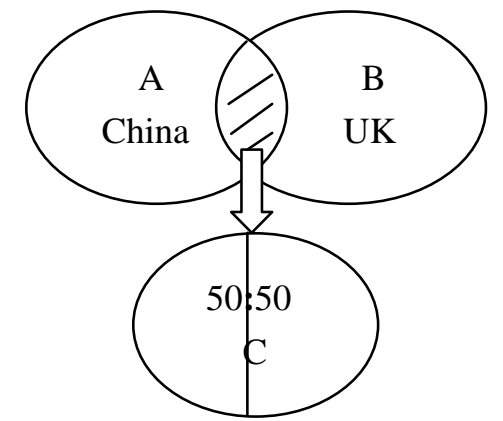

a (equity JV)

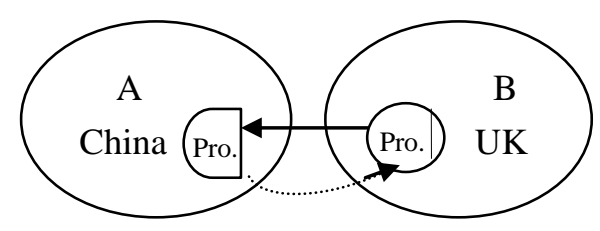

c (non-equity DB franchise)

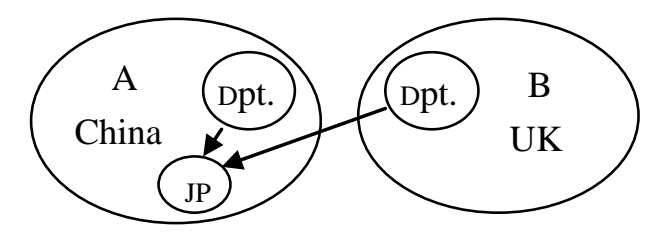

b (non-equity SB)

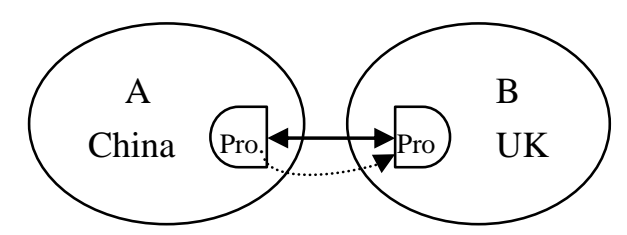

d (non-equity DB validation)

Key: Pro. $=$ program, $\mathrm{JP}=$ joint program, $\mathrm{Dpt} .=$ department, program movement $=$

Student movement: 